\title{
La costruzione scientifica della memoria: il caso della nuova antica città di Ninfa
}

\author{
Carlo Bianchini \\ Alessandro Viscogliosi \\ Francesca Cicinelli \\ Andrea Gallo
}

Abstract

II primo quarto di secolo di rivoluzione digitale ci ha ormai consegnato un ampio ventaglio di strumenti hardware e software che consentono ormai una significativa interazione tra il mondo reale e quello virtuale che sempre più pervasivamente innerva la nostra esperienza quotidiana.

Cuore di questa interazione è come noto il 'modello', ovvero quel simulacro virtuale di un elemento reale che in qualche modo rappresenta sia il fine che il mezzo di questa interazione. Se per molto tempo è stato il modello al centro dell'interesse di ricercatori e tecnici, più recentemente l'attenzione si sta piuttosto spostando verso il modellare, ovvero verso quel complesso di azioni e riflessioni che guidano il processo di 'costruzione' e 'informazion'e (nel senso di attribuzione di contenuto informativo) dei singoli elementi digitali che andranno insieme a comporre l'oggetto finale.

É dunque in questo contesto scientifico che si è sviluppata la ricerca sulla città di Ninfa con l'obiettivo di mettere alla prova le ipotesi descritte nel paragrafo precedente, ovvero tentare di ricostruire in modo scientificamente rigoroso la 'nostra version'e dell'antica struttura urbana. Scopo finale dei due anni di studio e analisi dedicati a Ninfa è stato tuttavia non solo la ricostruzione virtuale dell'abitato medievale ma soprattutto il tentativo di fornire uno strumento aggiuntivo per la comprensione della sua struttura e consistenza sia per fini di studio che di divulgazione/comunicazione.

Parole chiave

Ninfa, modellazione 3D, livello di affidabilità, anastilosi urbana.

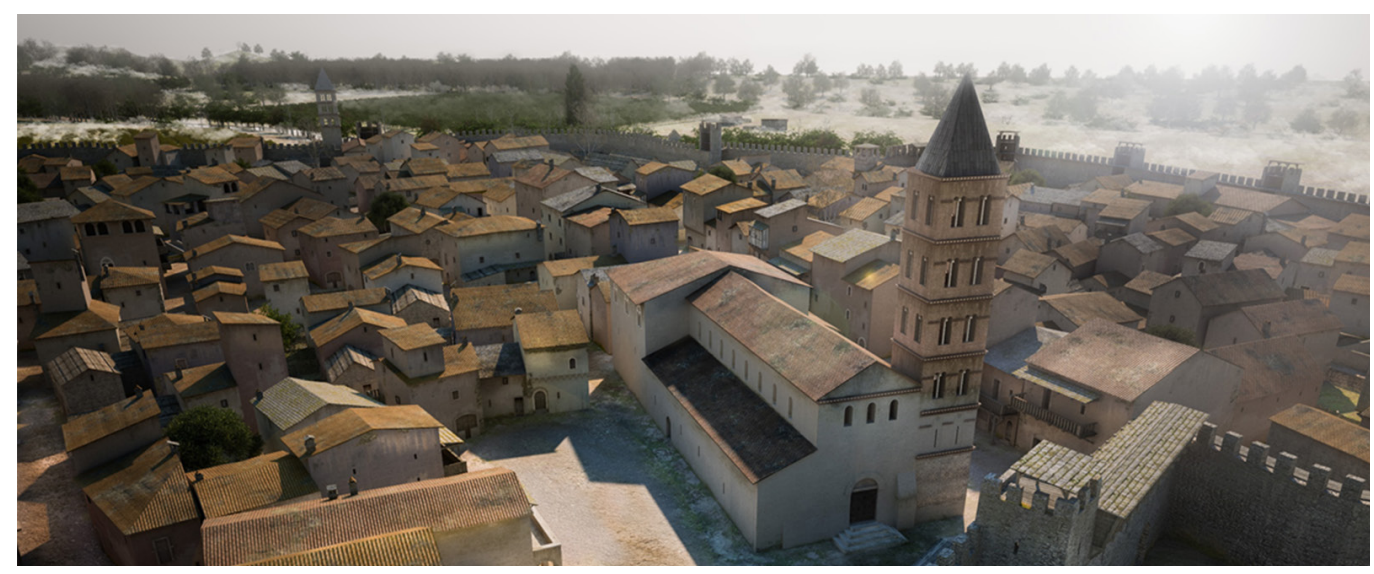




\section{Introduzione}

Il primo quarto di secolo di rivoluzione digitale ci ha ormai consegnato un ampio ventaglio di strumenti hardware e software che consentono ormai una significativa interazione tra il mondo reale e quello virtuale che sempre più pervasivamente innerva la nostra esperienza quotidiana.

Cuore di questa interazione è come noto il 'modello', ovvero quel simulacro virtuale di un elemento reale che in qualche modo rappresenta sia il fine che il mezzo di questa interazione [Bianchini et al. 20l6]. Se per molto tempo è stato il modello al centro dell'interesse di ricercatori e tecnici, più recentemente l'attenzione si sta piuttosto spostando verso il 'modellare', owero verso quel complesso di azioni e riflessioni che guidano il processo di "costruzione' e 'informazione' (nel senso di attribuzione di contenuto informativo) dei singoli elementi digitali che andranno insieme a comporre l'oggetto finale [Bianchini, Potestà 20 l8]. In questo senso, quindi, 'modellare 'corrisponde certamente a 'costruire' seguendo logiche e prassi non lontane rispetto a quanto tipicamente si fa in un cantiere: così come nella pratica costruttiva bisogna procedere ad una scomposizione analitica e catalogazione dei vari elementi costruttivi, ad una strutturazione delle fasi di lavorazione, all'allestimento del cantiere, allo stesso modo la costruzione di un modello 3D rispetta, pur con le debite differenze, la medesima sequenza.

Sia che si tratti di un edificio o di modello 3D, il prodotto finale sarà evidentemente il frutto delle capacità di coloro che ci hanno lavorato ma soprattutto dello loro scelte.

È questo forse il tema più rilevante dell'attività costruttiva: dare seguito, momento per momento, a scelte che guidano e a volte condizionano la realizzazione. Si tratta dunque di un vero e proprio processo di 'interpretazione' che di fatto consente ad un modello essenzialmente mentale di manifestarsi in forma materiale o numerica .

In questo senso la modellazione tridimensionale si configura come un vero e proprio processo euristico che non consente, come avviene ad esempio per i modelli grafici 2D (disegni), di lasciare indefinite ampie porzioni del modello poiché al contrario in un modello 3D tutto può divenire visibile e tutto si vede nel corso della sua esplorazione [Bianchini et al. 2017].

Questa caratteristica fornisce un grande ausilio certamente alla progettazione ma, se ci concentriamo sui soli oggetti reali o sulla ricostruzione dello stato di fatto di quelli che, non più esistenti, lo sono stati un tempo, allora il valore euristico dell'attività di modellazione 3D appare in tutta la sua evidenza.

In quest'ultimo caso, infatti, il modello 3D rappresenta la sintesi di un processo intellettuale prima che operativo con cui, chi costruisce il modello, rende palese la propria ipotesi ricostruttiva dell'oggetto. Questo processo passa innanzi tutto da una raccolta di dati e informazioni caratterizzati da livelli anche molto diversi di affidabilità oggettiva: si possono infatti prendere in considerazione rilievi, analisi metriche e geometriche, documentazioni fotografiche, rapporti, studi storici ma certamente anche appunti di viaggio, vedute, incisioni, affreschi e addirittura suggestioni o impressioni ricavate nel corso di un sopralluogo. E' poi compito di chi modella generare i vari oggetti digitali 3D che comporranno la sua ipotesi ricostruttiva e dotarli del necessario corredo informativo attingendo al database raccolto. Coesisteranno quindi in essa elementi caratterizzati da livelli diversi di affidabilità: da quelli tendenzialmente sicuri perché misurati o comunque altamente documentati ad altri invece del tutto ipotetici frutto di considerazioni personali e soggettive. Pertanto, la mappa dei vari livelli di affidabilità rappresenta a nostro avviso un metadato indispensabile a corredo di qualunque modello 3D ricostruttivo: non solo definisce apertamente il quadro informativo soggiacente utilizzato per la modellazione, ma è in grado di associare, elemento per elemento, forma, livello di incertezza, riferimento metrico e documentale. Per tutto quanto detto fin qui, non è evidentemente possibile pensare ad una siffatta attività se non in termini pluridisciplinari in cui la competenza in fase di modellazione si appoggi su un apparato documentale affidabile ma, soprattutto, su una capacità critica in grado di selezionare/interpretare i dati acquisiti a servizio di una ricostruzione scientificamente rigorosa [Viscogliosi 20I5]. 


\section{La nuova antica città di Ninfa}

È dunque in questo contesto scientifico che si è sviluppata la ricerca sulla città di Ninfa [I] che qui di seguito presentiamo. Questo sito architettonico-naturalistico del tutto particolare cela infatti, tra le centinaia di specie di fiori e piante del suo giardino allinglese, un'intera città medievale repentinamente abbandonata alla fine del XIV secolo e giunta fino a noi in forma quasi inalterata nella sua impronta originaria. Una città le cui rovine hanno, nei secoli, emanato una suggestione straordinaria e si sono rese protagoniste del fascino del luogo; un'attrazione non relegata al solo giardino come oggi può sembrare, poiché questo esiste soltanto a partire dagli anni '20 del Novecento. I resti medievali, spesso considerati mero impalcato per le oltre 1300 differenti specie naturali, rappresentano in realtà una componente essenziale poiché l'incanto del giardino deriva per buona parte dalla presenza continuamente rievocata dell'antica città.

Tuttavia, la consistenza e conformazione di Ninfa medievale semplicemente non è più leggibile, neppure dal satellite, visto il grado di fusione tra natura e architettura (fig. I). Ciò non-

Fig. I. Ninfa dal satellite.
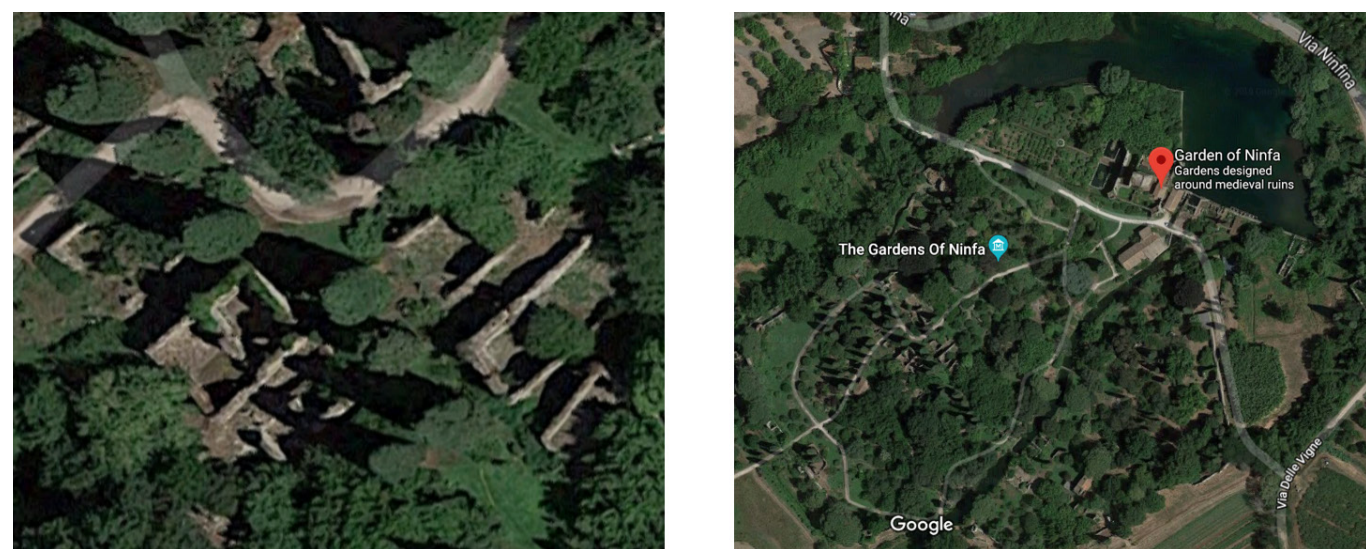

dimeno, data la rilevanza antica e presente del sito, è sembrato un tema straordinariamente adatto per mettere alla prova le ipotesi descritte nel paragrafo precedente, ovvero tentare di ricostruire in modo scientificamente rigoroso la nostra versione dell'antica struttura urbana. Scopo finale dei due anni di studio e analisi dedicati a Ninfa è stato tuttavia non solo la ricostruzione virtuale dell'abitato medievale ma soprattutto il tentativo di fornire uno strumento aggiuntivo per la comprensione della sua struttura e consistenza sia per fini di studio che di divulgazione/comunicazione.

In questo quadro, il progetto si si è sviluppato lungo due direttrici cardine: da un lato l'attendibilità storico-scientifica [AA.W. 1990] che la ricostruzione doveva possedere, dall'altro la capacità di assicurare una lettura efficace ad intuitiva dei modelli. Il percorso intrapreso è dunque partito dalla ricerca storico-archivistica e dalla individuazione, spesso per analogia stilistica, degli elementi e delle finiture caratterizzanti gli edifici in epoca medievale. In parallelo è stata condotta poi un'estensiva campagna di rilievo integrato delle strutture architettoniche ancora visibili. Queste operazioni hanno trovato un concreto punto di convergenza in un modello 3D ricostruttivo della città che, fondendo geometria e consistenza dei resti, tipi architettonici medievali, rappresentazioni urbane di contesti coevi, desse conto di come doveva presentarsi il sito al momento del suo abbandono.

Porzioni dell'abitato sono risultate di immediata e facile ricostruzione grazie alla consistente presenza di fonti storiche e resti ben visibili: le chiese; il castello; la cinta muraria esterna e interna; le varie strutture rilevate in buono stato di conservazione (ad esempio le numerose case sul corso) (fig. 2). 
Fig. 2. L'impianto urbano di Ninfa medievale: le unità edilizie ad alta affidabilità.

Fig. 3. Ninfa: ricostruzione grafica del corso principale.

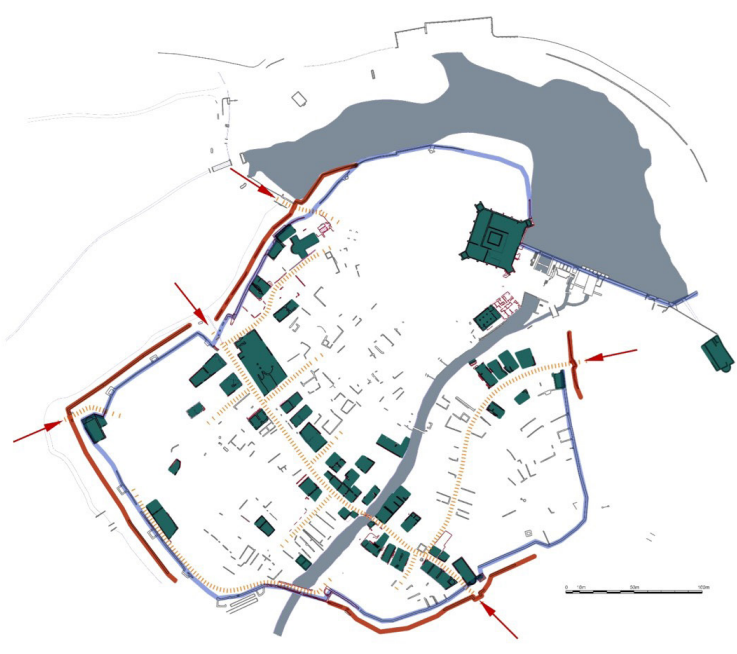

È stato così possibile ricavare piante e alzati di numerosi edifici, alcuni percorsi principali che caratterizzavano l'impianto urbano e le porte ricavate nelle cinte murarie (fig. 3).

La ricognizione diretta dei resti peggio conservati unitamente a rilievi fotogrammetrici ha permesso, dapprima, di allineare le intercapedini (elementi caratteristici delle architetture medievali infine), quindi ricostruire l'andamento dei fronti dei vari edifici assieme alla loro consistenza volumetrica e, infine, ipotizzare la posizione delle direttrici dell'impianto urbanistico meno evidenti (fig. 4).

Nonostante gli sforzi, tuttavia, molte sono rimaste le porzioni dell'impianto urbano non sufficientemente definite soprattutto perché le strutture vegetali del giardino spesso celano una non trascurabile quantità di resti murari affioranti dal terreno.

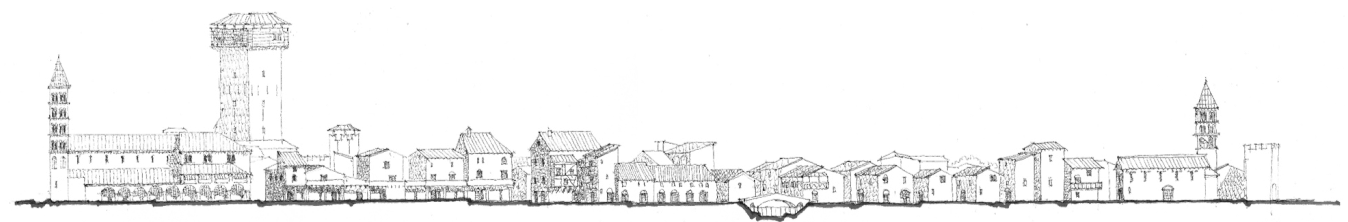

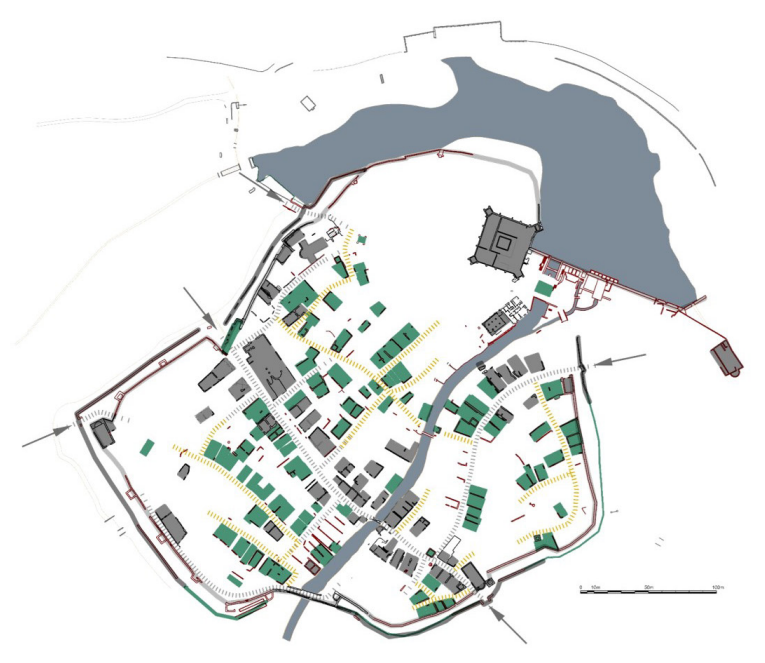


Fig. 5. L'impianto urbano di Ninfa medievale: le unità edilizie di bassa uffidabilità.
Per queste ampie porzioni di Ninfa non era dunque possibile procedere applicando lo schema fin qui utilizzato: per riuscire a completare il tessuto urbano si sono dunque dovuti accettare alcuni compromessi che all'aumentare della soggettività delle ipotesi ricostruttive diminuivano la loro affidabilità generale.

Secondo questo approccio si sono individuati i nodi irrisolti più significativi dell'organismo (la piazza del mercato, la piazza d'armi, la diga e le strutture necessarie allo sfruttamento delle acque) e colmati i relativi vuoti comparandoli con impianti urbani analoghi.

Tali operazioni hanno consentito di completare i percorsi di collegamento e di restituire una densità urbana credibile e coerente con le analisi svolte e i dati disponibili (fig. 5).

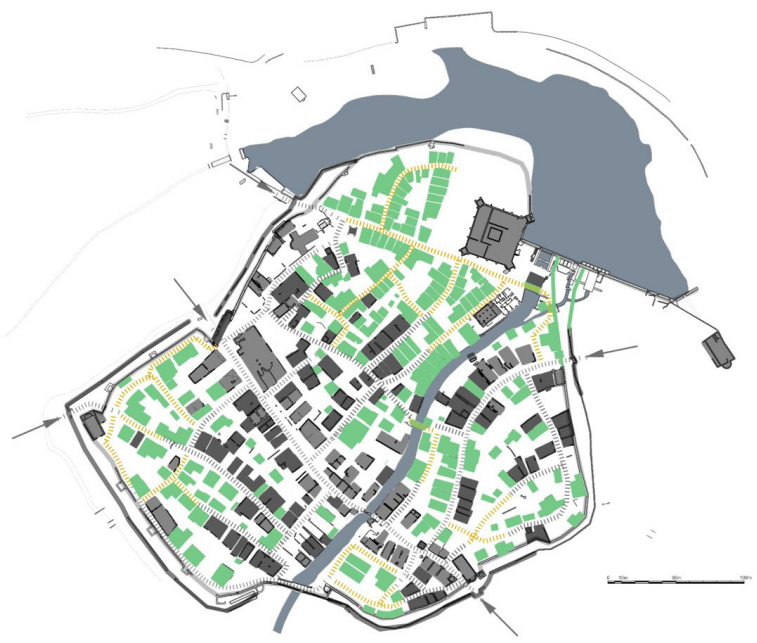

Messa così a punto l'intera volumetria dell'abitato, il passo successivo è consistito nel ricostituire il volto degli antichi edifici di Ninfa, ovvero nell'ipotizzare quale potesse essere la tipologia e l'immagine dei singoli manufatti e della città nel suo complesso. Essenziale è stato da questo punto di vista lo studio delle tipologie edilizie [De Minicis 1990] (fig. 6) murature e

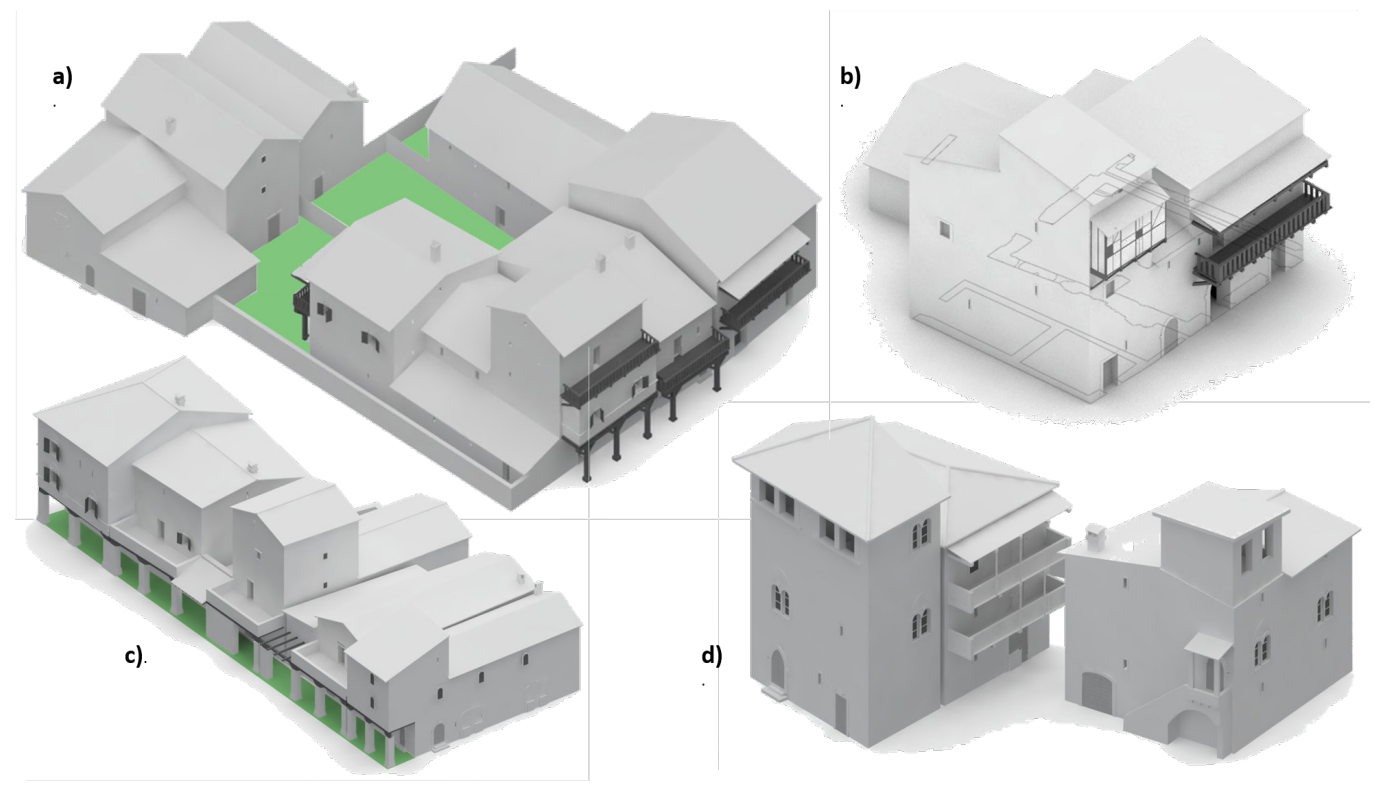


Fig. 7. Ninfa: tracce cromatiche su parament murario esistente.

Fig. 8. Ambrogio Lorenzetti, L'allegoria degli effetti del buon governo, 1338

Fig. 9. La tipizzazione cromatica sulla base della campionatura sull'affresco di Lorenzetti.

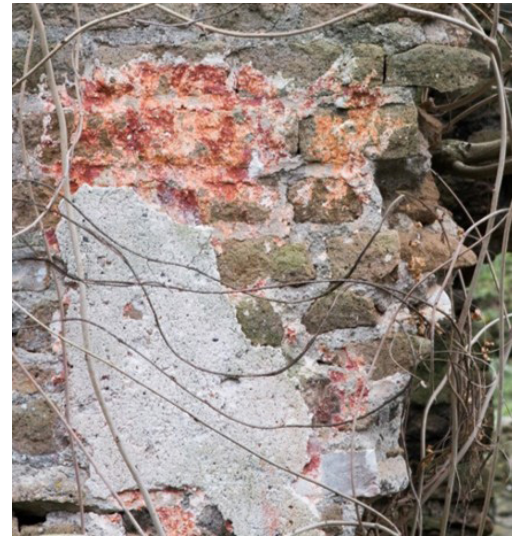

degli intonaci condotto sui resti visibili direttamente sul posto [Fiorani 1996; Esposito 1998] (fig. 7). Dai numerosi sopralluoghi sono infatti emersi diversi elementi circa il trattamento superficiale degli edifici: nell'antica Ninfa, di fatto, l'uso dell'intonaco non era limitato alla sola protezione del paramento murario ma aveva anche un'importante funzione decorativa, enfatizzata da tinte vivaci e ricercate. Contrariamente alla comune idea che si ha delle città medievali, che vede gli edifici spogliati degli intonaci e privi degli apparati decorativi, le piazze, gli edifici e i luoghi di culto si presentavano con caratteri cromatici molto vari e distintivi come attestato da varie fonti storiografiche e dai numerosi studi sulliconografia medievale che, concordemente, ci restituiscono una città variamente ed eterogeneamente colorata [Frommel,Wolf 2019]. Paradigma tra i numerosi esempi nell'arte pittorica medievale a sostegno di quest'affermazione è certamente L'allegoria degli effetti del buon governo di Ambrogio Lorenzetti (fig. 8) in cui vediamo ritratto un brano ampiamente policromo di città medievale.
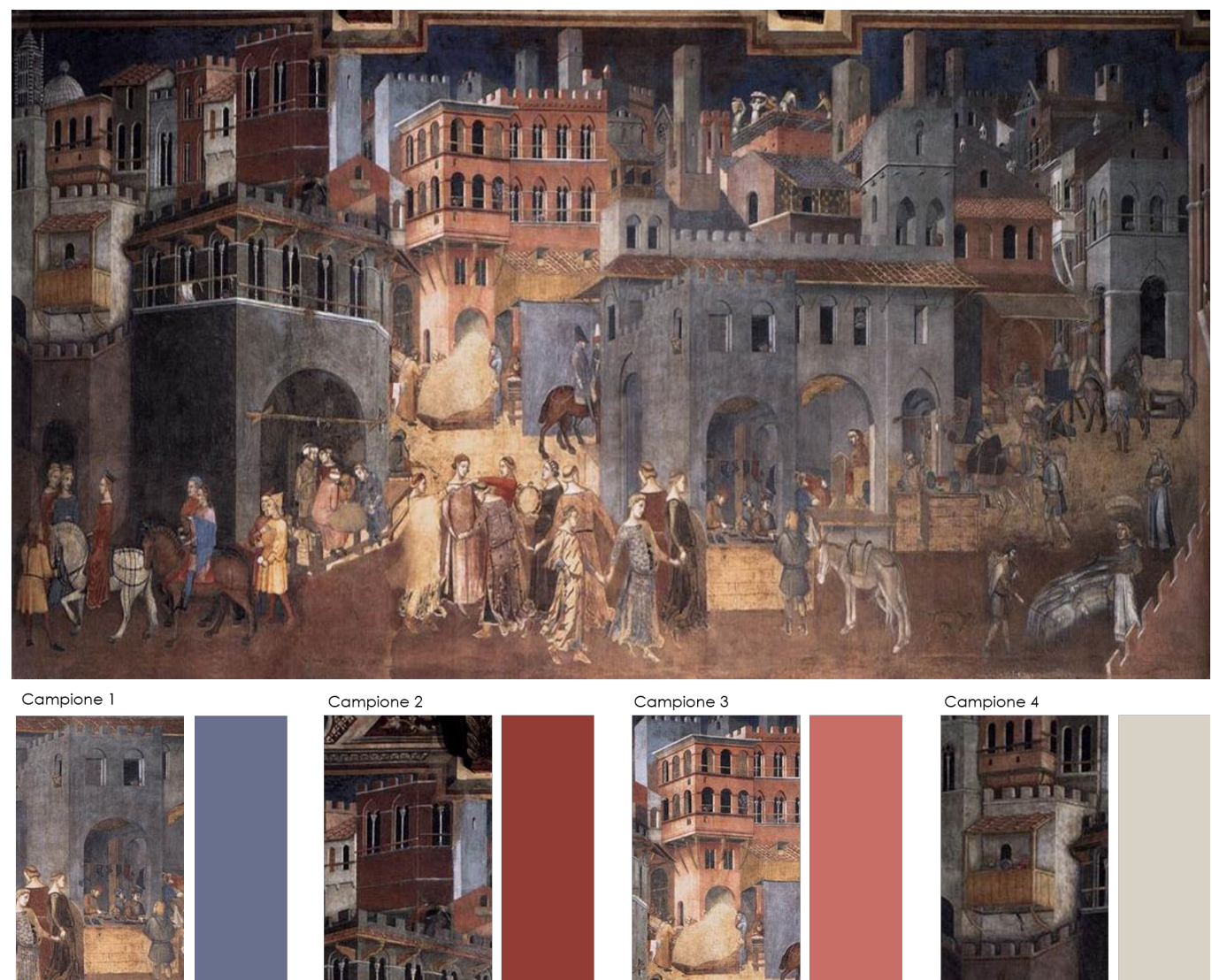

Campione 2

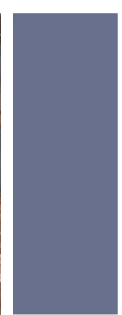

Campione 3
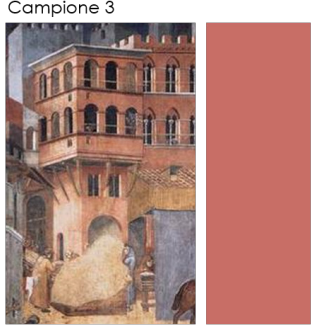

Campione 4

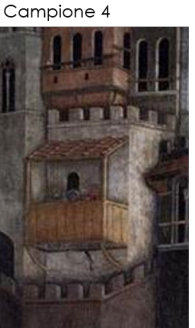


Fig. 10. Ricostruzione di Ninfa medievale: visualizzazione 3D dei livelli di affidabilità dal più elevato (più scuro) al più basso (più chiaro).
Fig. I I. Ricostruzione di Ninfa medievale: vista generale renderizzata dell'abitato.

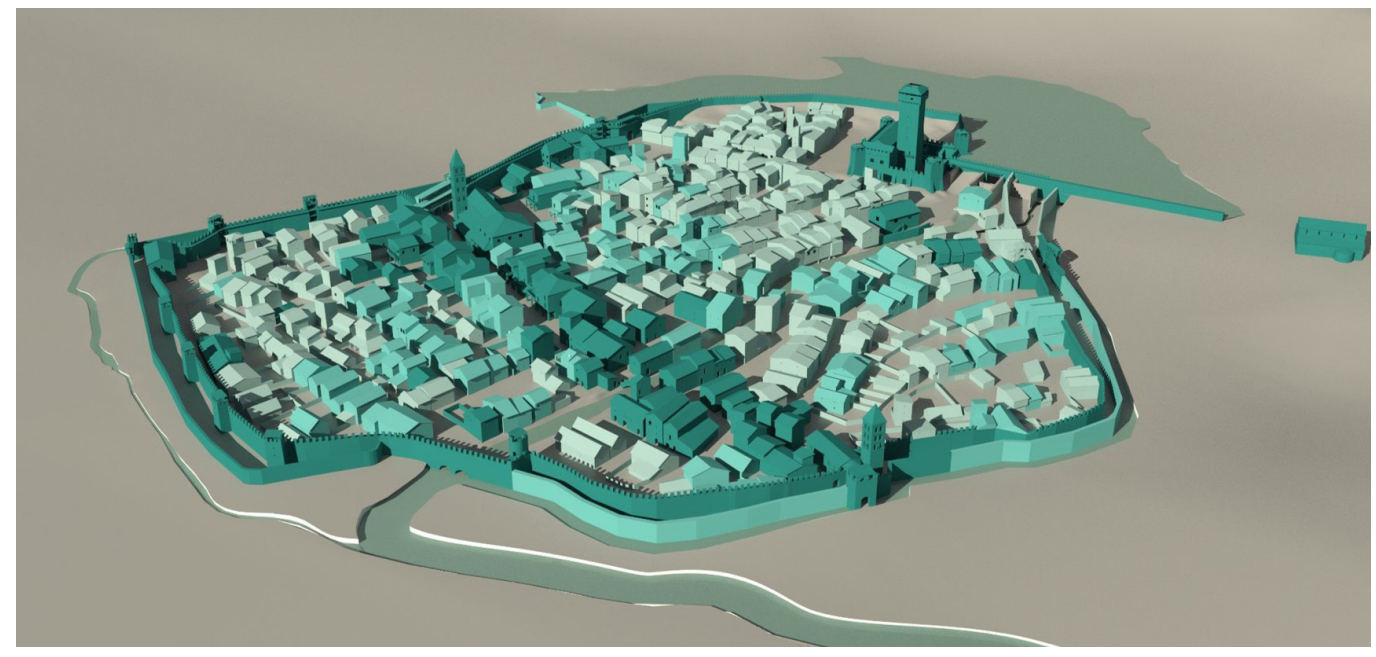

Ebbene, per quegli edifici per i quali non è stato possibile rinvenire tracce delle finiture originali, abbiamo pertanto scelto di rifarci alle cromie proprio di questo affresco attribuendo in forma del tutto soggettiva i vari colori e tipi di finitura agli edifici della nostra nuova antica città di Ninfa.

Campionati dunque i colori dell'affresco più significativi e condotta un'attenta ricerca circa la reale possibilità di produrre nel periodo alto medievale e in quel luogo materiali con la cromia individuata, si è proceduto a determinare la palette di colori che avrebbero caratterizzato il trattamento superficiale dei nostri edifici modellati (fig. 9).

A valle di queste operazioni, la nostra versione di Ninfa medievale era di fatto completa e pronta per essere sottoposta a letture diverse a seconda delle esigenze dei vari utenti: da quella scientifica rivolta a studiosi ed esperti, a quella più divulgativa rivolta invece ad un pubblico più vasto e generalista.

Agli estremi, forse, della suddetta gamma di prodotti troviamo da un lato le letture dell'abitato in relazione ai livelli di affidabilità del modello ricostruttivo (fig. I0), dall'altro invece alcune suggestive immagini fotorealistiche (figg. I I, I2).

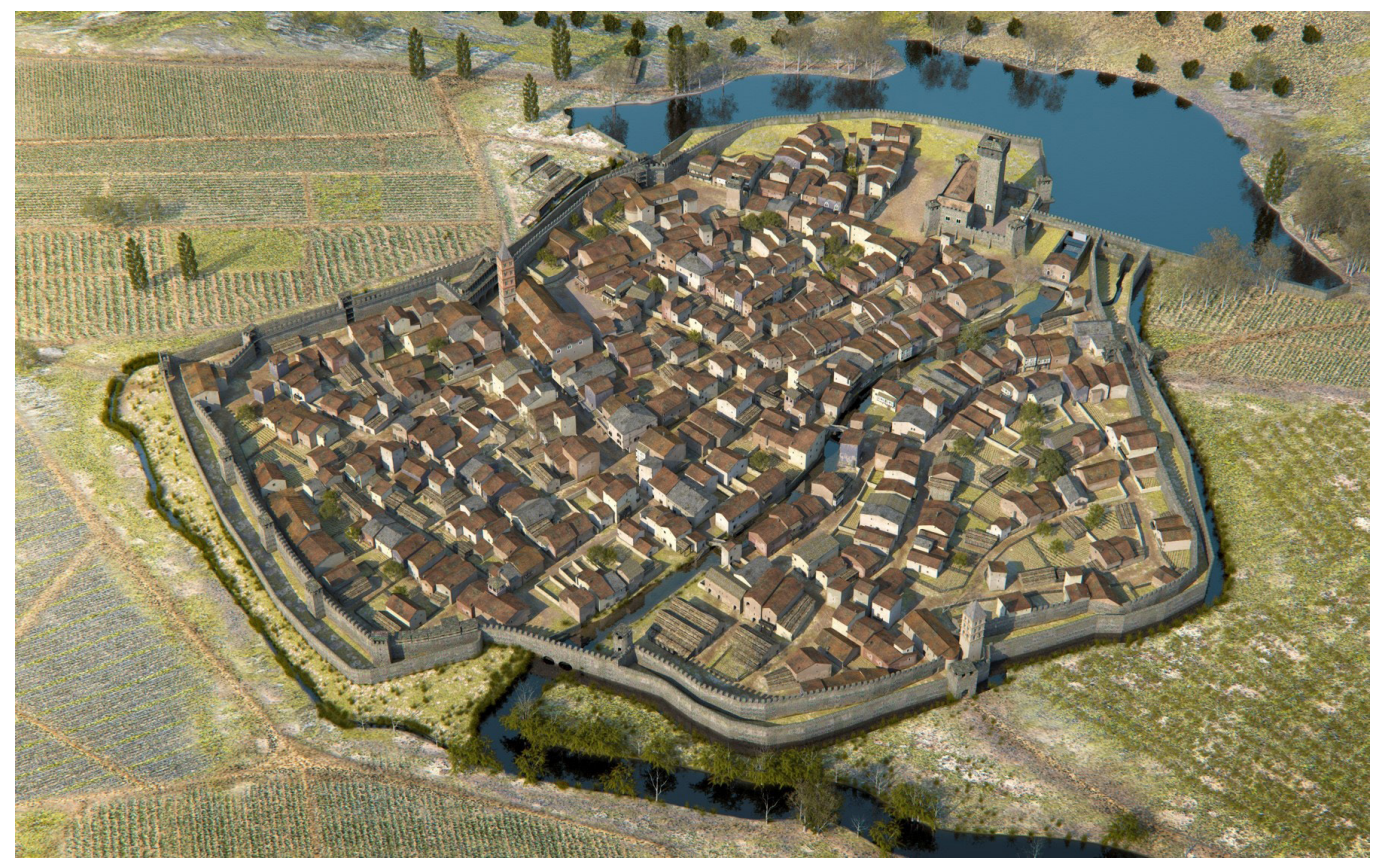




\section{Conclusioni}

Questa ricerca di fatto restituisce non una delle migliori ricostruzioni lì e allora (forse in realtà lo è anche...) ma certamente una delle più esplicite in termini di valutazione del livello di affidabilità che ha tutti i requisiti per presentarsi come 'buona pratica' di una metodologia operativa in grado di dimostrare una volta per tutte il valore intrinseco dei modelli 3D non solo dal punto di vista comunicativo ma anche da quello propriamente scientifico.

I due termini tuttavia non sono affatto disgiunti: comunicazione (anche semplicemente divulgativa) e ricerca scientifica di fatto si sostengono a vicenda, specie nel settore dell'architettura e più generalmente dei beni culturali. Modelli interpretativi più affidabili risultano infatti anche più comprensibili e completi (essendo semplicemente più studiati in profondità!) e suscettibili di essere utilizzati come base anche per prodotti a vocazione divulgativa, turistica o addirittura per il gaming, il cinema o ad altri settori comunque collegati alle cosiddette cultural and creative industries.

La ricostruzione virtuale dell'intera città offre inoltre un importante strumento per la valorizzazione dell'offerta del complesso monumentale del giardino di Ninfa nella sua interezza, grazie all'impiego di nuove soluzioni tecnologiche e modelli di fruizione capaci di offrire al pubblico forme inedite di comprensione e coinvolgimento. Ma la stessa salvaguardia del luogo potrà utilmente appoggiarsi sul database di cui i rendering rappresentano forse il prodotto meno interessante: a Ninfa, più che in ogni altro luogo, si deve infatti operare con interventi di restauro minimi, necessari unicamente alla sopravvivenza del monumento così come oggi si presenta. È quindi fondamentale cristallizzare le rovine realizzando solo piccole e indispensabili azioni puntuali di restauro proprio affinché la potenza evocativa data dal binomio natura-architettura non possa in alcun modo essere alterata. Le giuste esigenze di ricostituire l'originaria immagine della città, che un tempo si sarebbero trasformate in pesanti interventi reali su strutture reali, oggi possono essere utilmente sostituite da tecnologie che permettono, virtualmente, di dare corpo a qualunque ipotesi reintegrativa, di visualizzarla e di esplorarla interattivamente.

Fig. 12. Ricostruzione di Ninfa medievale: vista renderizzata dell'abitato dal Castello verso sud.

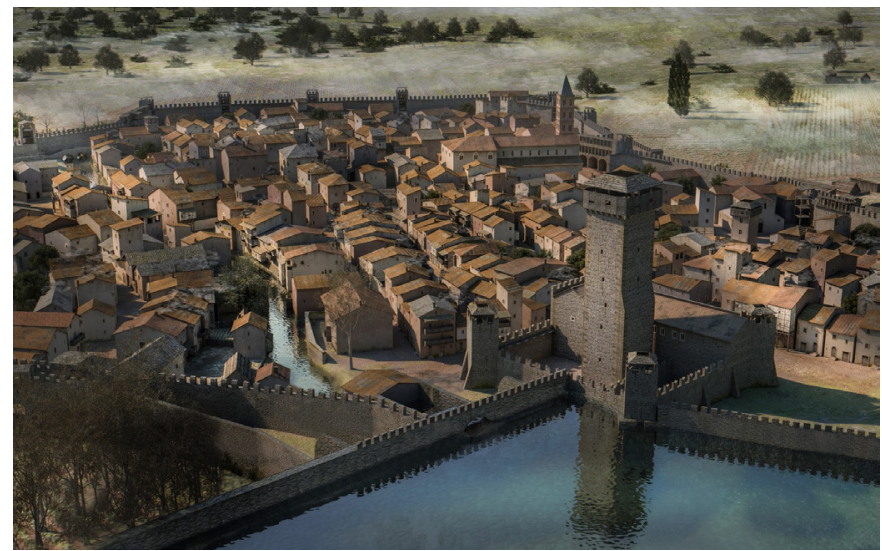

Note

[I] Già esistente in epoca romana, Ninfa era a quel tempo solo un piccolo paese di agricoltori. Entrata a far parte dei possedimenti di Papa Zaccaria nell'VIII secolo, con l'avanzare della palude pontina che rese impraticabili la via Appia e la via Severiana, Ninfa e Sermoneta assunsero un ruolo via via crescente data la loro vicinanza alla via Pedemontana preferita per gli spostamenti lungo la direttrice nord-sud. Ninfa divenne successivamente dogana decretandone così la definitiva affermazione. A seguito dello scisma del I 59 in cui vennero eletti i Papi Vittore IV e Alessandro III, quest'ultimo venne addirittura consacrato a Ninfa, episodio che determinò il successivo incendio e saccheggio della città da parte di Federico Barbarossa che sosteneva invece Vittore IV. Nel XIV secolo, sotto il dominio della famiglia Caetani, Ninfa vide l'ampliamento della cinta muraria e del lago, la costruzione delle torri, delle chiese e dei mulini ad acqua divenendo un dinamico centro di manifattura e commercio. Nel 1369 però, all'apice di una faida tra i Caetani e i Colonna, Ninfa venne di nuovo saccheggiata ma questa volta distrutta irrimediabilmente e abbandonata.

Del vivace e importante centro medievale rimangono oggi solo i ruderi inglobati dal famosissimo giardino, un vero e proprio monumento naturale, conosciuto anche all'estero come uno dei parchi più belli d'Italia. Ė noto che Ninfa sia stata ammirata in tutte le epoche, ancora prima che fosse creato il giardino che tutti oggi conosciamo. Nel 1873, lo storico e medievista tedesco Gregorovius la descrive come un luogo invaso da piante e fiori, un sito dove la natura selvaggia predomina. Un luogo ben diverso dal giardino all'inglese in seguito progettato e pensato da Gelasio prima e da Lelia Caetani a partire dagli anni Venti del $X X$ secolo. 


\section{Riferimenti bibliografici}

AA. W. (1988). Ninfa. Una città, un giardino. Atti del Colloquio della Fondazione Camillo Caetani. Roma, Sermoneta, Ninfa, 7-9 ottobre 1988, Fondazione Camillo Caetani. Roma: L'Erma di Bretschneider.

Bianchini Carlo (2007). Dal Reale al Virtuale (e ritorno): il modello ligneo di Antonio da Sangallo per il Nuovo San Pietro in Vaticano. In Disegnare idee immagini, n. 34, pp. 36-49.

Bianchini Carlo, Inglese Carlo, Ippolito Alfonso (20 I 6). I Teatri Antichi del Mediterraneo come esperienza di rilievo integrato. Roma: Sapienza Edizioni.

Bianchini Carlo, Potestà Giorgia (2018). The critical reconstruction of the Temple-Theatre complex in the Italic Sanctuary of Pietrabbondante. In 2018 3rd Digital Heritage International Congress (DigitalHERITAGE) held jointly with 20I8 24th International Conference on Virtual Systems \& Multimedia (VSMM 20 I 8). IEEE, 20 I8. pp. I-4.

Bianchini Carlo, Viscogliosi Alessandro, Aglietti Alessandro (2017). Innovative digital heuristic approaches in architectural historical research. In Information Visualisation (IV), 2 I st International Conference IEEE, pp. 444-449.

Borghini Stefano, Carlani Roberto (20II). La restituzione virtuale dell'architettura antica come strumento di ricerca e comunicazione dei beni culturali: ricerca estetica e gestione delle fonti. In DisegnareCon, 4, 8, pp. 72-79.

Broise Henri, Vigueur Jean-Claude Marie (1983). Strutture familiari, spazio domestico e architettura civile a Roma alla fine del Medioevo. In Storia dell'arte italiana, I2, Momenti di Architettura, pp...

De Minicis Elisabetta (1986). Strutture murarie a Roma: alcuni esempi di edilizia civile. Notizie preliminari. In Archeologia medievale, XIII.

De Minicis Elisabetta (1990). Lo studio della casa medievale: analisi e proposte di metodo. In Storia della città, 52.

Cecchelli Carlo (1935). Per una raccolta di studi e di rilievi sulle case medievali romane. In Atti del III Congresso Nazionale di Studi Romani. Bologna, pp. 73-74.

De Minicis Elisabetta, Guidoni Enrico (a cura di). (1996). Case e torri medievali, I. Roma: Kappa, pp. I30-200.

De Minicis Elisabetta, Guidoni Enrico (a cura di). (200 I). Case e torri medievali, II. Roma: Kappa, pp. I5- I5 I; I78- I88.

De Minicis Elisabetta, Guidoni Enrico (a cura di). (2005). Case e torri medievali, III. Roma: Kappa, pp. 22 I-237.

Docci Mario, Bianchini Carlo, Ippolito Alfonso (20 I I). Papers for a theory of architectural survey. In: Disegnare. Idee Immagini n. 22, pp. 34-41

Esposito Daniela (1998). Tecniche costruttive murarie medievali. Murature a tufelli in area romana. Roma: L'Erma di Bretschneider Fiorani Donatella (1996). Tecniche costruttive murarie medievali: il Lazio meridionale. Roma: L'Erma di Bretschneider.

Frommel Sabine, Wolf Gerhard (a cura di). (20l6). Architectura picta nell'arte italiana da Giotto a Veronese. Modena: Franco Cosimo Panini.

Guidoni Enrico (a cura di). (1999). Città medievali : orientamenti e metodi di ricerca. Roma: Kappa.

Mancini Rossana, Udina Cristina (1998). La cinta muraria della città di Ninfa. In Quaderni dell'Istituto di Storia dell'Architettura, 3 I.

Marchetti Longhi Giulia (1935). Per la ricostruzione di un quartiere medievale in Roma. In AAVV. Atti del III Congresso Nazionale di Studi Romani. II, Bologna, pp. 63-72.

Marchetti Longhi Giulia (1955). Ninfa "Città del sogno". In Capitolium, XXX, 8, pp. 239-246.

Parenti Roberto (1988). Sulle possibilità di datazione e di classificazione delle murature. In Francovich Riccardo, Parenti Roberto (a cura di). Archeologia e Restauro dei monumenti. Firenze: Quaderni del Dipartimento di Archeologia e Storia delle arti, pp. 280-304.

Viscogliosi Alessandro (20I5). Lo studio della Storia dell'Architettura fra tradizione e high-tech. In: Disegnare Idee Immagini, 51 , pp. 80-90

\section{Autori}

Carlo Bianchini, Sapienza Università di Roma, carlo.bianchini@uniromal .it

Alessandro Viscogliosi, Sapienza Università di Roma, alessandro.viscogliosi@uniromal .it

Francesca Cicinelli,ARCHA srl, f.cicinelli@archaprogetti.com

Andrea Gallo, ARCHA srl, a.gallo@archaprogetti.com

Per citare questo capitolo: Bianchini Carlo,Viscogliosi Alessandro, Cicinelli Francesca, Gallo Andrea (2020). La costruzione scientifica della memoria: il caso della nuova antica città di Ninfa/The scientific construction of memory: the case of the new ancient city of Ninfa. In Arena A., Arena M., Brandolino R.G., Colistra D., Ginex G., Mediati D., Nucifora S., Raffa P. (a cura di). Connettere. Un disegno per annodare e tessere. Atti del $42^{\circ}$ Convegno Internazionale dei Docenti delle Discipline della Rappresentazione/Connecting. Drawing for weaving relationships. Proceedings of the 42th International Conference of Representation Disciplines Teachers. Milano: FrancoAngeli, pp. 1760- 1777. 


\title{
The Scientific Construction of Memory: the Case of the New Ancient City of Ninfa
}

\author{
Carlo Bianchini \\ Alessandro Viscogliosi \\ Francesca Cicinelli \\ Andrea Gallo
}

\section{Abstract}

The first 25 years of the so-called digital revolution have produced a wide 'bundle' of hardware and software tools paving the way to an actual interaction between our real world and its virtual version. Our lives are day by day more influenced by the possibilities offered by these tools.

Core of this interaction is the model, namely the virtual simulacrum of a real element, which represents the aim and the medium of this interaction.

While for many years now the model has been the main source of problems and interest for scholars and technicians, more recently the focus has been shifting towards the modelling. This last term does not refer in fact to the simple output, but better to the set of thoughts and actions guiding the process of construction and information (in the sense of defining an informative content) of all digital elements composing, together, the final object.

This is the scientific context of the research on the ancient city of Ninfa presented in this paper.The aim of our work was to test the hypothesis described in the previous paragraph: in other words to address the rigorous and scientific reconstruction of our version of that urban settlement. Not only the virtual reconstruction of the medieval city has been the final goal of our two years long activity, but also the setup of an additional tool for its understanding both for study and communication purposes.

Keywords

Ninfa, 3D modelling, level of reliability, urban anastylosis.

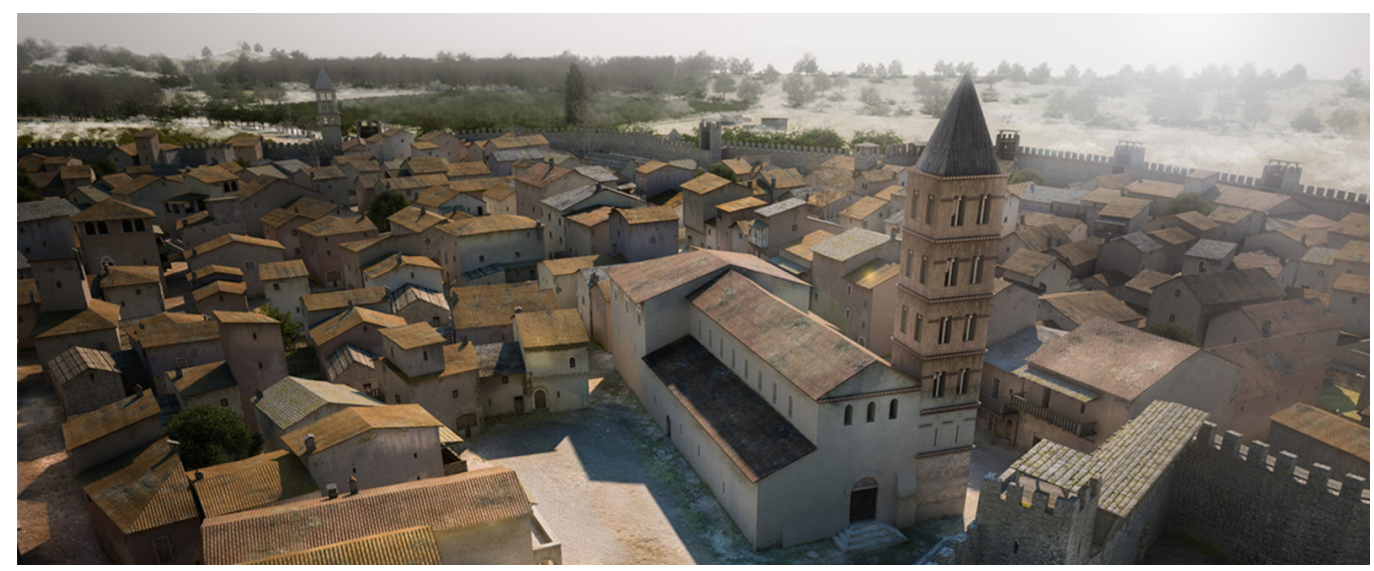




\section{Introduction}

The first 25 years of the so-called 'digital revolution' have produced a wide 'bundle' of hardware and software tools paving the way to an actual interaction between our real world and its virtual version and our lives are day by day more influenced by the opportunities offered by these tools.

Core of this interaction is the model, namely the virtual simulacrum of a real element, which represents the goal and the medium of this interaction [Bianchini et al. 2016].

While for many years now the model has been a major topic of research (and concern) for scholars and technicians, more recently the focus has been shifting towards the modelling. This last term does not refer in fact to the simple output, but better to the set of reflections and actions guiding the process of construction and information (in the sense of defining an informative content) of all digital elements composing, together, the final object [Bianchini, Potestà 20 l8].

From this standpoint, modelling certainly implies constructing following logical and practical rules not afar from those that typically govern a construction site. In fact, as in the building practice we must break up the fabric into an analytic catalogue of elements and organize the site and the sequence of all working phases, in the same way the construction of a 3D model must respect more or less the same workflow and constraints. Furthermore, regardless the output (building or 3D model), the outcome will actually be the product of the skills of those involved in the construction process and above all of their choices.

This last is maybe the more relevant issue of any constructive activity: make, moment by moment, choices that guide and obviously influence the construction itself. In other words, an interpretation process that transforms what is essentially a mental model into a material or numerical one. In this framework, the construction of 3D models is a real heuristic process: differently from graphic 2D models (drawings), in fact, in a 3D model you cannot afford to leave undefined any portion of the object, as anything can become visible and anything is visible during its exploration [Bianchini et al. 2017].

This feature certainly represents a great help for designers, but if we focus on existing objects or on the reconstruction of those not existing any more, the heuristic value of the modelling activity becomes paramount indeed.

In this last case, in fact, the 3D model represents the synthesis of that process, more intellectual than operative, the modeller (i.e. the maker of the model) has used to show his/her reconstructive hypothesis. The preliminary step of this workflow is certainly an as much as possible complete collection of data and information. This bundle can include a variety of materials showing the widest range of objective reliability: surveys, metric and geometric analysis, photographs, reports, historical investigations but also travel notes, views, engravings, paintings, frescos, and even suggestions or impressions emerged while visiting the site.

Thus, it is the modeller's task to create all the 3D digital objects necessary to compose his/ her reconstructive hypothesis and to provide them with enough information using the collected database as main source.

In this digital environment will coexist elements with different levels of reliability that could spam from those almost certain due to measurement or exhaustive documentation to others highly conjectural and subjective.

Therefore, a map representing these different levels of reliability is in our opinion an essential attribute for any 3D reconstructive model. It clearly defines in fact not only the informative framework laying underneath the modelling phase, but can also connect to each element attributes like shape, level of accuracy, metric and documentary reference.

As a result, it is not possible to conceive the task described so far not but in a multidisciplinary form. The modelling skills must in fact come together with a sound documentary collection and, above all, with a critical ability to select/interpret the acquired data and information aiming at a rigorous and scientific reconstruction [Viscogliosi 20 I5]. 


\section{The new ancient city of Ninfa}

We have presented so far the scientific background of this project involving the city of Ninfa [I]. Amid and under the hundreds of plants and flowers that enrich its world famous English garden, this unusual site hides in fact an entire medieval settlement suddenly abandoned at the end of the XIV century. This catastrophic event has transformed the city in a scattered composition of ruins that nature has in time repossessed.

This peculiar evolution has on the one hand created an extraordinary site rich of fascination for poets and travellers, but on the other has actually protected the original layout of the ancient city under the vegetation. In other words, an attraction relying at the same time on the existing garden (that goes back only of one hundred years) and the medieval remains. These last, in fact, are often considered only as the sub-structure for the I 300 natural species and more of the garden while, on the contrary, the continuous recall of the ancient city is the essential ingredient of Ninfa's charm.

However, the shape and consistency of the medieval settlement is currently invisible: not even satellite images can help in this task due to the tangle of nature and architecture (fig. I).
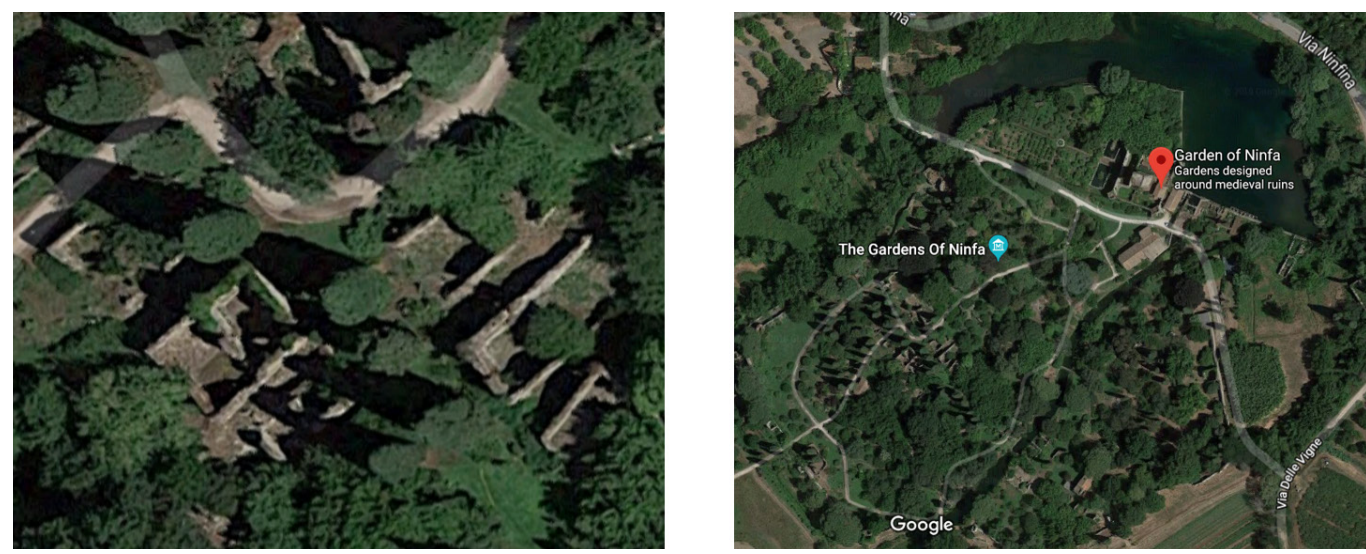

Nevertheless, the absolute relevance of the site (both ancient and present) led us to test and validate the reconstructive approach described in the previous paragraph.

Thus, considering Ninfa as an extraordinary appropriate study case, we addressed the problem of reconstructing in a scientific rigorous way our version of the ancient urban structure. Together with the virtual anastylosis of the medieval city, the ultimate goal of our two years' long investigations was to set up an additional tool for the reading of its structure and consistency both for study and dissemination/communication purposes.

In this framework, our research has proceeded along two main directions: on one side our reconstruction must highly respect the historical scientific method [AA.VV. 1990]: on the other, though, it must ensure an effective and intuitive reading of models. Our work, in fact, has started from a systematic archival and historical research and from the selection of those architectural elements and details we recognized as typical of the settlement's period. Together with this task, often based on stylistic analogy, we performed an extensive integrated survey of the structures still visible.

All these different activities have led to a reconstructive 3D model of the city, namely a first synthesis among geometry, current layout of remains, medieval architectural typologies, representations of contemporary urban settlements. Such a model aims at showing what was the ancient Ninfa like just before its leaving.

Some portions were easily and immediately modelled due to rich historical sources and clear remains: the churches, the castle, the outer and inner faces of city walls and, in general, all elevated structures fairly preserved (i.e. several houses located on the main street) (fig. 2) 
Fig. 3. Ninfa: graphic reconstruction of the main street.

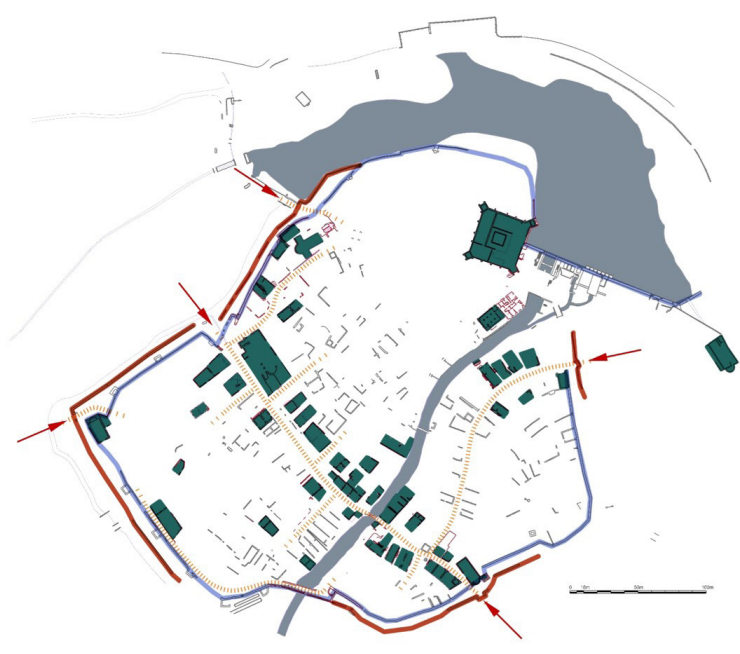

We reconstructed the plans and elevations of these buildings together with some important streets of the urban settlement and the gates in the city walls (fig. 3 ).

Direct inspection of the worse preserved remains together with photogrammetric surveys led us first to the alignment of the narrow gaps left between the walls of two adjacent units (a typical feature of Ninfa's medieval buildings), then to the reconstruction of their façades and volumes and, finally, to suggest the position of other less evident axes in the urban layout (fig. 4).

Despite our efforts, we could not put together enough information for many portions of the city, especially because the vegetal structures of the garden permanently hide a relevant percentage of Ninfa's aboveground remains. Therefore, the workflow we setup have demonstrated not applicable to these cases.

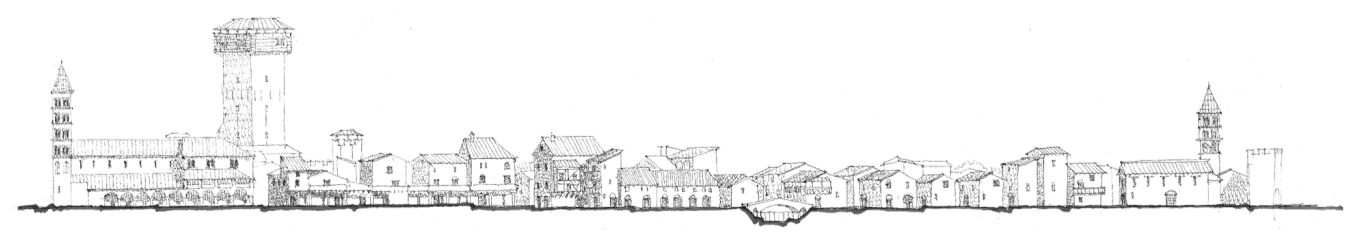

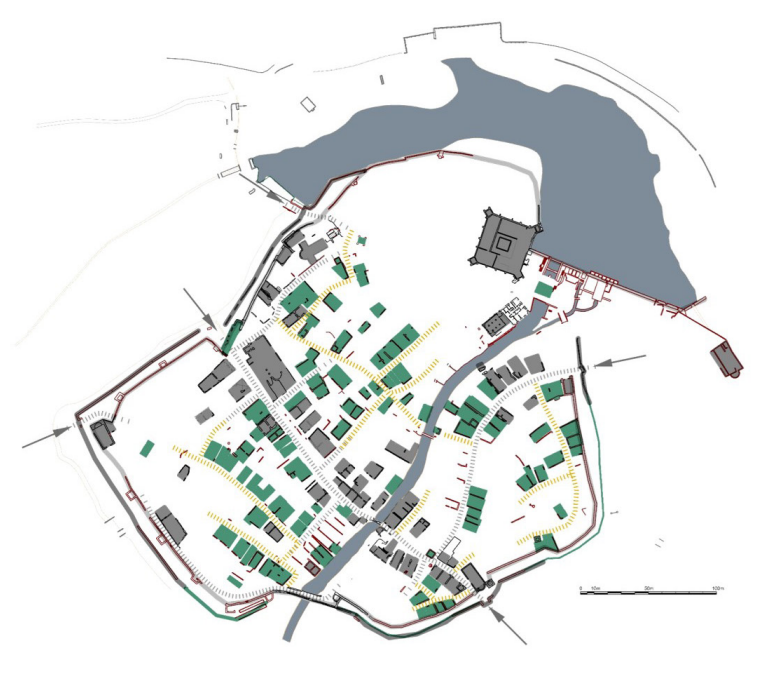


Fig. 5. The urban structure of medieval Ninfa: low level of reliability units.
We had to change strategy in order to complete the task of modelling the whole city, actually readdressing our work to a lower standard in comparison with those used for the structures discussed so far. In other words, we accepted that some portions of the final model would result as less reliable being affected by a higher level of subjectivity.

In accordance with this approach, we outlined the most relevant unclear nodes of the urban organism (the market square, the parade ground, the dam and the related hydraulic structures) and proceeded to their reconstruction by comparing them to similar contemporary examples.

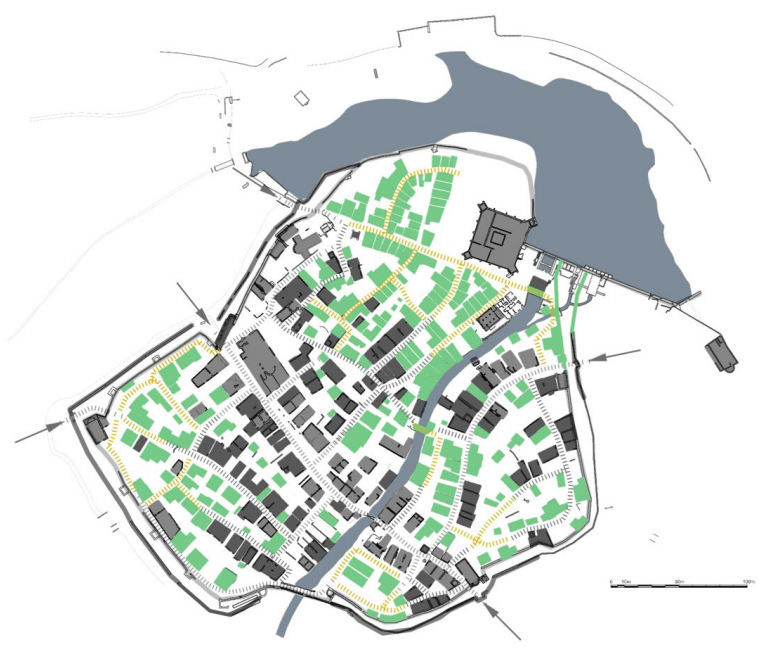

The reconstructive model of ancient Ninfa, at this stage, was thus consistent with the data and information collected, coherent with the strategy adopted and complete as for the streets' net and the density of built structures (fig. 5)

We then passed to consider the outfit of all fabrics. We tried to define the different typologies, outline the image of streets and buildings and, eventually, of the entire city. In the task we took into great account the general studies carried out on buildings [De Minicis 1990] (fig. 6) and

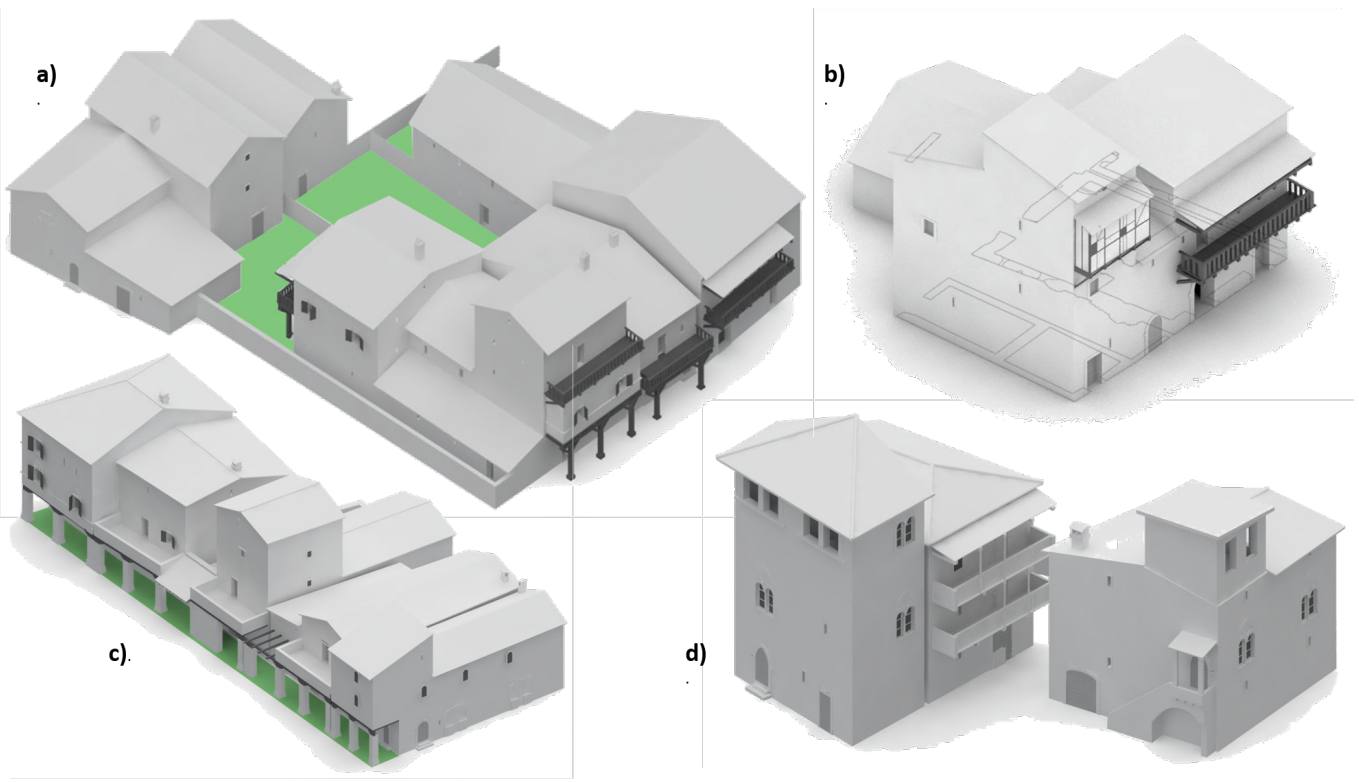


Fig. 7. Ninfa: colour traces of an existing wall.

Fig. 8. Ambrogio Lorenzetti, Lallegoria degli effetti del buon governo, 1338

Fig. 9. The colour characterization referenced to Lorenzetti fresco.

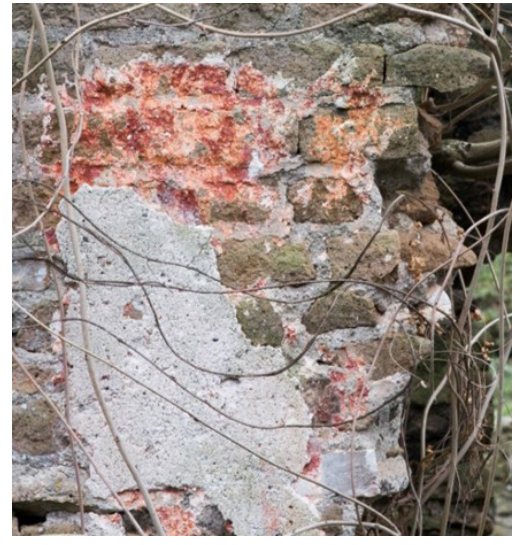

the past onsite masonry and plaster coverings investigations [Fiorani 1996; Esposito 1998] (fig. 7).

Specific inspections have also revealed some additional evidences about the superficial finishing of Ninfa's buildings in the Middle Ages. At that time, in fact, plaster was used not only to protect the masonry underneath, but also as an important decorative finishing emphasized by vivid and refined shades.

Contrary to the common idea we might have of medieval cities (buildings deprived of plaster and without decorations), squares, houses, shops, churches were rich in colours that often worked as a distinctive trait within the city complex. Historiographical sources and many studies focussing on medieval iconography have clearly depicted, in fact, medieval cities as variably and heterogeneously coloured [Frommel, Wolf 2019].

L'allegoria degli effetti del buon governo by Ambrogio Lorenzetti (fig. 8) certainly represents a paramount evidence of how much polychrome a medieval city could have appeared.

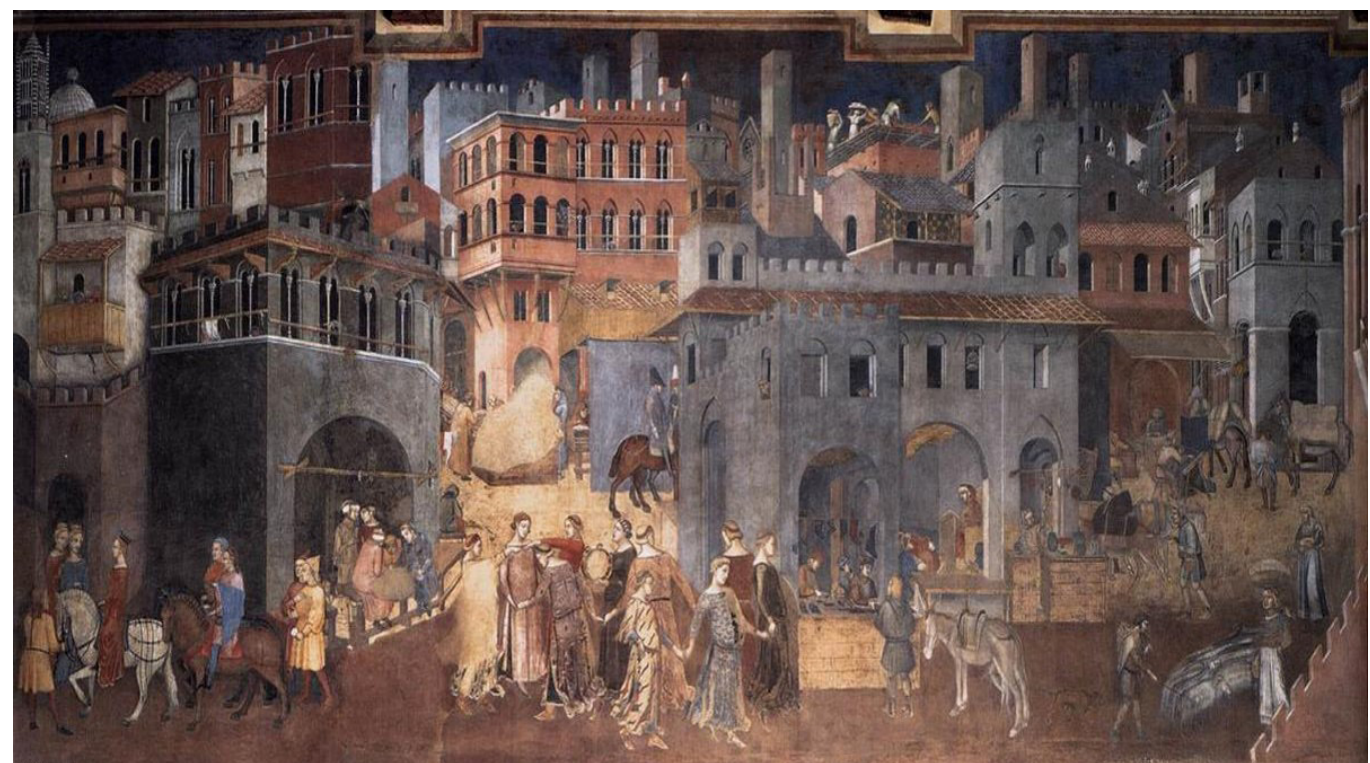

Campione 1

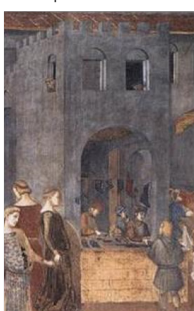

Campione 2

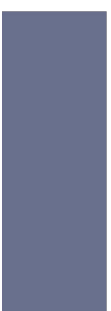

Campione 3

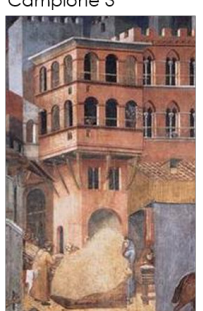

Campione 4

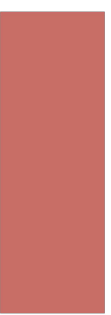

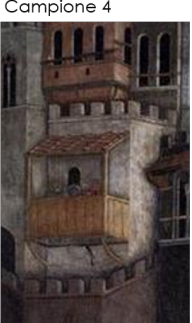


Fig. 10. The reconstruction of medieval Ninfa: 3D representation of the different level of reliability from the highest (darker) to the lowest (lighter).

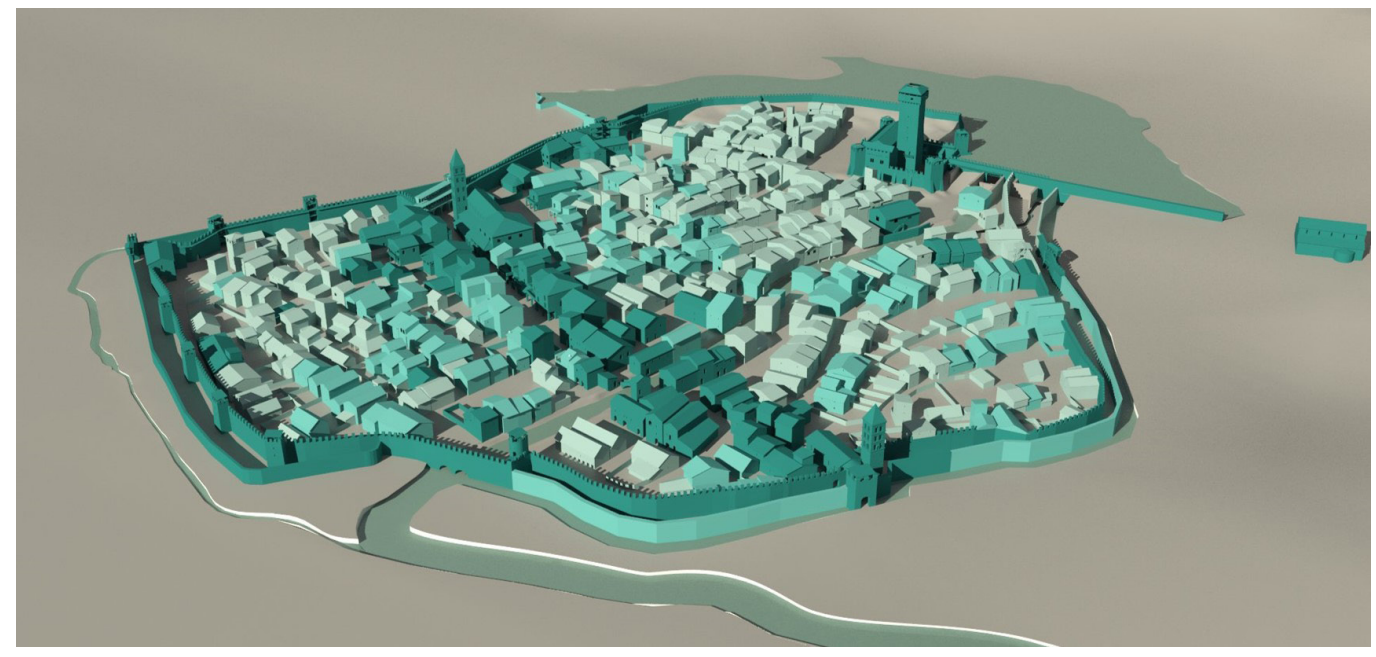

Thus, for those buildings we could not find any trace of the original finishing, we chose to refer to the colourings of this fresco and, consequently, to subjectively establish the colours and type of finishing for the different fabrics of the new ancient city of Ninfa.

We coupled the sampling on the painting of the most appropriate colours and shades of the buildings with an accurate feasibility check about the production of that specific material and colour in that specific area in that specific historical period. The outcome of this challenging task has been a palette of colours to be used for the texturing of our digital objects (fig. 9). This has been the final step of our work leading to our first release of the complete 3D Model of ancient Ninfa. A model addressing, as we planned, different reading levels and needs: from the scientific one for scholars to the communicative more intended for lay users. Specific representations actually show these different levels: on one extreme, so to speak, the models in false colours representing the different levels of reliability of each digital object (fig. I0); on the other instead, the more suggestive photorealistic images (figs. $|1|$,2 ).

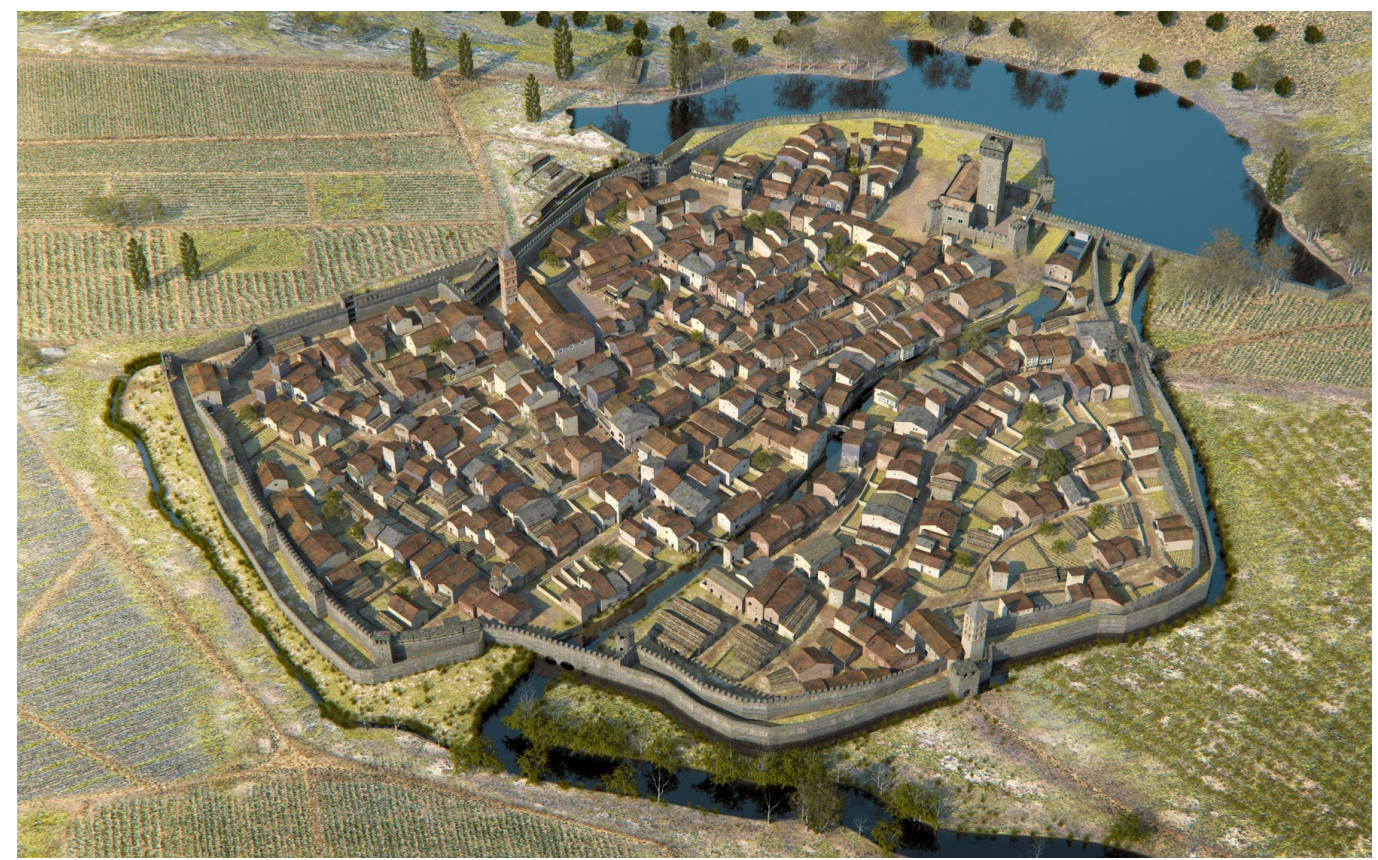




\section{Conclusion}

The research presented in this paper does not intend to provide the best reconstruction of ancient city of Ninfa (maybe it could a good one though...), it aims instead at presenting a reconstructive workflow where all digital objects must undergo a multidisciplinary check and a transparent benchmarking in terms of reliability. In other words, it aims at defining a general methodology by means of a good practice as demonstrator where the value of 3D models clearly exceeds the traditional communication level and achieve the scientific one. However, these last two terms do not indicate separate worlds: communication (even if simply popular) and scientific research are actually faces of the same medal, especially in the architectural and cultural heritage fields. More reliable interpretative models are in fact more complete (coming from more accurate studies) but generally also easier to understand. They can be used also as base materials in many sectors (i.e. didactic, touristic etc.) and particularly in those fields embraced by the so-called cultural and creative industries like gaming and film industry.

Finally, the virtual reconstruction could be an important tool for the development of the entire cultural and touristic potential (garden and city) offered by the Garden of Ninfa monumental complex.This digital product, in fact, could pave the way both to innovative fruition paths for the visitors and to a more effective management and preservation of the site. Besides and beyond the 3D model and its capturing representations, in fact, a major role could be played by the database underneath where all the information collected is archived and ready for use for other purposes.

In Ninfa, more than elsewhere, works must create the least possible impact so that a rigorous maintenance program is to replace urgent or emergency restoration. The main task here is to crystalize the built remains through small and limited interventions not to spoil the evocative power of the site coming from the duo nature-architecture.

The worthy aspiration to reconstruct the original image of Ninfa, that once would have implied heavy, real interventions on the remains, today can instead be replaced by virtual interventions that not only respect the tangled charm of the site but also disclose the possibility of authoring, embodying, visualizing and exploring different interpretation of the same subject. What an enrichement!

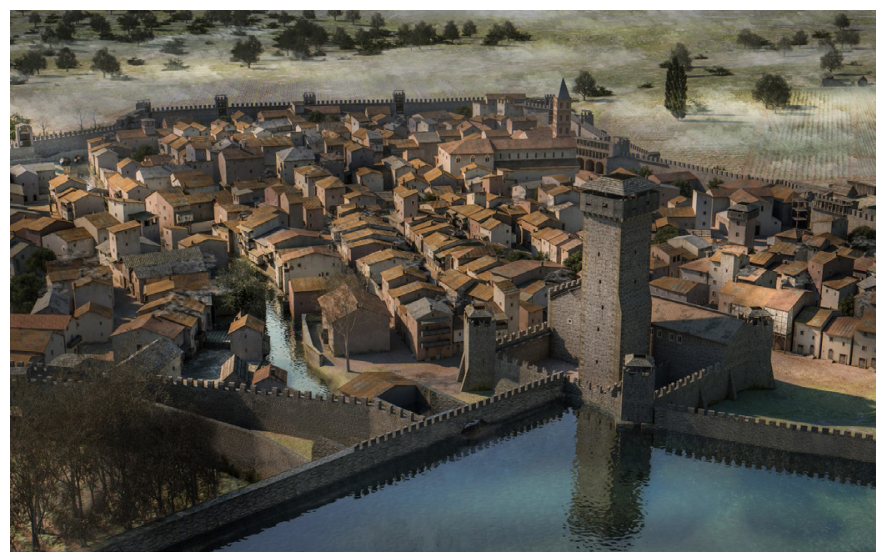

Notes

[I] The city of Ninfa was a small village of farmers already in Roman times. In the 8th century, it became a possession of Pope Zaccaria increasing (together with Sermoneta) its relevance due to the expansion of the Pontine Marshes. Ninfa became in fact an important node along the north south Pedemontana route highly preferred by travellers and merchants in that period. The establishment in Ninfa of a custom office also witnesses this increasing role. At the time of the schism that led to the election of two Popes ( 1 159), Ninfa had become such a high-ranking city to host the ceremony of consecration of Alessandro III. However, after this event the city was fired and ransacked by Frederick I Barbarossa that was supporting Vittore IV, the other elected Pope. During the I 4th century, under the domain of Caetani family, Ninfa was highly renovated and expanded: the city walls were extended, its towers built together with new churches and water mills. Ninfa became in that period a dynamic centre of manufacturing and trading. In 1369 an unfortunate climax in the feud between Caetani and Colonna families led to a new ransack of Ninfa that this time was irreparably destructed and abandoned by its inhabitants. Only the ruins incorporated by the garden suggest today the presence of that lively, important medieval city. 
After this event Ninfa laid in ruin for centuries, but the site has been always admired for its combination of nature and ruins far before becoming the garden we all know.

In 1873, the German mediaevalist Gregorovius describes in fact Ninfa as a place occupied by plants and flowers where the wild nature prevails. A place much different from the English garden imagined and designed by Gelasio and Lelia Caetani since the 20 s of the 20th century. The complex presently is an actual naturalistic monument well acknowledged all around the world as one of the most beautiful parks in Italy.

\section{References}

AA. W. (1988). Ninfa. Una città, un giardino. Atti del Colloquio della Fondazione Camillo Caetani. Roma, Sermoneta, Ninfa, 7-9 ottobre 1988, Fondazione Camillo Caetani. Roma: L'Erma di Bretschneider.

Bianchini Carlo (2007). Dal Reale al Virtuale (e ritorno): il modello ligneo di Antonio da Sangallo per il Nuovo San Pietro in Vaticano. In Disegnare idee immagini, n. 34, pp. 36-49.

Bianchini Carlo, Inglese Carlo, Ippolito Alfonso (20 I 6). I Teatri Antichi del Mediterraneo come esperienza di rilievo integrato. Roma: Sapienza Edizioni.

Bianchini Carlo, Potestà Giorgia (2018). The critical reconstruction of the Temple-Theatre complex in the Italic Sanctuary of Pietrabbondante. In 2018 3rd Digital Heritage International Congress (DigitalHERITAGE) held jointly with 2018 24th International Conference on Virtual Systems \& Multimedia (VSMM 20 I 8). IEEE, 20 I8. pp. I-4.

Bianchini Carlo, Viscogliosi Alessandro, Aglietti Alessandro (2017). Innovative digital heuristic approaches in architectural historical research. In Information Visualisation (IV), 2 I st International Conference IEEE, pp. 444-449.

Borghini Stefano, Carlani Roberto $(20 \mathrm{l}$ I). La restituzione virtuale dell'architettura antica come strumento di ricerca e comunicazione dei beni culturali: ricerca estetica e gestione delle fonti. In DisegnareCon, 4, 8, pp. 72-79.

Broise Henri, Vigueur Jean-Claude Marie (1983). Strutture familiari, spazio domestico e architettura civile a Roma alla fine del Medioevo. In Storia dell'arte italiana, 12, Momenti di Architettura, pp....

De Minicis Elisabetta (1986). Strutture murarie a Roma: alcuni esempi di edilizia civile. Notizie preliminari. In Archeologia medievale, XIII.

De Minicis Elisabetta (1990). Lo studio della casa medievale: analisi e proposte di metodo. In Storia della città, 52.

Cecchelli Carlo (1935). Per una raccolta di studi e di rilievi sulle case medievali romane. In Atti del III Congresso Nazionale di Studi Romani. Bologna, pp. 73-74.

De Minicis Elisabetta, Guidoni Enrico (a cura di). (1996). Case e torri medievali, I. Roma: Kappa, pp. I30-200.

De Minicis Elisabetta, Guidoni Enrico (a cura di). (200 I). Case e torri medievali, II. Roma: Kappa, pp. I5- I5 I; I78- I88.

De Minicis Elisabetta, Guidoni Enrico (a cura di). (2005). Case e torri medievali, III. Roma: Kappa, pp. 22 I-237.

Docci Mario, Bianchini Carlo, Ippolito Alfonso (20 I I). Papers for a theory of architectural survey. In: Disegnare. Idee Immagini, n. 22, pp. 34-4I.

Esposito Daniela (1998). Tecniche costruttive murarie medievali. Murature a tufelli in area romana. Roma: L'Erma di Bretschneider. Fiorani Donatella (1996). Tecniche costruttive murarie medievali: il Lazio meridionale. Roma: L'Erma di Bretschneider.

Frommel Sabine, Wolf Gerhard (a cura di). (2016). Architectura picta nell'arte italiana da Giotto a Veronese. Modena: Franco Cosimo Panini.

Guidoni Enrico (a cura di). (1999). Città medievali : orientamenti e metodi di ricerca. Roma: Kappa.

Mancini Rossana, Udina Cristina (1998). La cinta muraria della città di Ninfa. In Quaderni dell'Istituto di Storia dell'Architettura, 31 .

Marchetti Longhi Giulia (1935). Per la ricostruzione di un quartiere medievale in Roma. In AAVV. Atti del III Congresso Nazionale di Studi Romani. II, Bologna, pp. 63-72.

Marchetti Longhi Giulia (1955). Ninfa "Città del sogno". In Capitolium, XXX, 8, pp. 239-246.

Parenti Roberto (1988). Sulle possibilità di datazione e di classificazione delle murature. In Francovich Riccardo, Parenti Roberto (a cura di). Archeologia e Restauro dei monumenti. Firenze: Quaderni del Dipartimento di Archeologia e Storia delle arti, pp. 280-304.

Viscogliosi Alessandro (20I5). Lo studio della Storia dell'Architettura fra tradizione e high-tech. In: Disegnare Idee Immagini, 51 , pp. 80-90.

\section{Authors}

Carlo Bianchini, Sapienza Università di Roma, carlo.bianchini@uniromal.it

Alessandro Viscogliosi, Sapienza Università di Roma, alessandro.viscogliosi@uniromal.it

Francesca Cicinelli, ARCHA srl, f.cicinelli@archaprogetti.com

Andrea Gallo, ARCHA srl, a.gallo@archaprogetti.com

To cite this chapter. Bianchini Carlo, Viscogliosi Alessandro, Cicinelli Francesca, Gallo Andrea (2020). La costruzione scientifica della memoria: il caso della nuova antica città di Ninfa/The scientific construction of memory: the case of the new ancient city of Ninfa. In Arena A., Arena M., Brandolino R.G., Colistra D., Ginex G., Mediati D., Nucifora S., Raffa P. (a cura di). Connettere. Un disegno per annodare e tessere. Atti del $42^{\circ}$ Convegno Internazionale dei Docenti delle Discipline della Rappresentazione/Connecting. Drawing for weaving relationships. Proceedings of the 42th International Conference of Representation Disciplines Teachers. Milano: FrancoAngeli, pp. 1760-1777. 